\title{
Tourism-phobia in historic centres: the case of Malaga
}

Turismofobia en los centros históricos: el caso de Málaga

\section{Fernando Almeida-García}

falmeida@uma.es

\section{Rafael Cortés-Macías}

rcortes@uma.es

Departamento de Geografía

(i3t) Instituto Universitario de Investigación de Inteligencia e Innovación Turística

Universidad de Málaga (Spain)

\section{Antonia Balbuena-Vázquez}

\author{
abalvaz@yahoo.es \\ Departamento de Geografía \\ Universidad Nacional de México (UNAM)
}

\begin{abstract}
The annoyance presented by the residents in the historic centre of Malaga, due to the impact of tourism is analysed. The study area is affected by a declining population and problems presented by residents in intense tourism spaces. The existence of tourism-phobia and the elements involved in it are examined. To this end, a specific questionnaire was produced about tourism-phobia, 378 surveys were distributed and completed and 10 semi-structured interviews were carried out with residents. Likewise, a thematic map was created, spatially identifying the main problems relating to the nuisances to residents. This research is the first study that analyses tourism-phobia by using statistically reliable samples. The results show the existence of a group of residents who are quite
\end{abstract}


annoyed (17.5\%) that can be classified as tourism-phobic and a group that is not very annoyed at all $(22.2 \%)$ that could be classed as tourism-philic. There are sociodemographic variables that are essential to interpreting these attitudes, such as the cases of the level of education and place of residence. The spatial distribution of the perceptions of the annoyance caused by tourism is uneven in the historic centre of Malaga.

Key words: residents, tourism-phobia; historic centres; overtourism; tourism management.

\section{Resumen}

Se analizan las molestias que presentan los residentes en el centro histórico de Málaga, debido a los impactos del turismo. La zona de estudio está afectada por la pérdida de población y por molestias que presentan los residentes en espacios intensamente turísticos. Se indaga sobre la existencia de la turismofobia y los elementos que intervienen en la misma. Para ello se elaboró un cuestionario específico sobre turismofobia, se distribuyeron y cumplimentaron 378 encuestas y se llevaron a cabo 10 entrevistas semiestructuras a residentes. Así mismo, se confeccionó una cartografía temática que identifica espacialmente los principales problemas relacionados con las molestias a residentes. Esta investigación es el primer estudio que analiza la turismofobia utilizando muestras estadísticamente fiables. Los resultados señalan la existencia de un colectivo de residentes bastante molesto $(17,5 \%)$ que se pueden denominar como turismofóbicos, y un grupo bastante poco molesto $(22,2 \%)$, que se podría designar como turismofílicos. Hay variables sociodemográficas que son claves para interpretar estas actitudes, como son los casos del nivel de estudios y lugar de residencia. La distribución espacial de las percepciones de las molestias debido al turismo es desigual en el centro histórico de Málaga.

Palabras clave: residentes; turismofobia; centros históricos; sobreturismo; gestión turística.

\section{Introduction}

At present, the negative and positive impacts generated by tourism are well-known, depending on the different narratives of the stakeholders relating to this activity. In tourism research, there are a large number of studies that deal, above all, with the positive economic impact deriving from tourism and its contribution to economic, social and cultural development, especially the generation of revenue, jobs and cultural contacts, among other aspects (Cannonier \& Galloway, 2018; Comerio \& Strozzi, 2019). However, to a lesser extent, other studies have pointed out the existence of different negative impacts, especially environmental and economic ones, with social and cultural 
impacts receiving less attention. In general, studies relating to impacts have revolved around the need to adapt tourist activity to the principles of sustainable development and to the participation of local communities in tourism development processes (Butler, 1999; Richards \& Hall, 2003; Harrill, 2004).

The enormous tourism growth experienced in recent years by some tourist destinations such as Barcelona, Venice, Paris, Palma de Mallorca, to mention just some, has shown the existence of a certain social protest movement in the face of this growth; and, on the other hand it shows that the intense growth affecting several destinations is part of a global phenomenon that generates similar problems to the globalisation of tourism intensity. In recent years, the perception of residents of tourist areas affected by intensification of tourism or overtourism, has changed from a positive or neutral vision to overt annoyance or irritation, which has generated a certain debate that has been conveyed in the media, an innovative aspect in the field of tourism. Regularly, almost since the start of mass tourism, in almost every country the media has depicted tourism as an activity unrelated to political or social criticism. Also, the existence of social movements in the local communities affected has been an important factor. The problems identified by the most affected destinations are similar, such as the excessive exploitation of natural and cultural resources, the privatisation of public spaces, displacement, labour exploitation and residential tourism speculation (Hiernaux, 1999; Bonilla \& Mortd, 2008; Blázquez \& Cañada, 2011; Sosa \& Jiménez, 2010; Cañada, 2010).

Some centres and historic cities suffer the consequences of the process of commercially exploiting their resources and public spaces and the role of the residents is relegated to the background (Rivera \& Rodríguez, 2012). These historic centres have become a space devoted exclusively to leisure, where the processes of gentrification and dramatization mostly correspond to the concept of a "themed city" for tourism (Baptista, 2005), that creates new places and uses for tourists and not for residents. These problems have acquired a special significance in the most important historic centres and those global brands or distinctions, especially the ones that are World Heritage sites. The problems of the local population in these spaces increase in relation to other tourism spaces; intense mass tourism, depopulation, increased rental and property prices, the disappearance of traditional business, property speculation, noise, dirt, problems with civic coexistence, difficulty and limitations of access, the lack of facilities for the population, the disappearance of spaces for the local population to socialise, among others. 
Malaga is an example of a city that has experienced strong growth and tourist transformation within a short space of time. This process is especially observed in the intense increase in visitors and tourist apartments, alongside the disappearance of the activities and traditional functions of the historic centre. Malaga is currently withstanding similar impacts to the aforementioned cities. The local population is observing that its usual environment is being occupied by activities aimed at attracting tourists, and it feels alienated and excluded from its own space.

The objective of this study is to analyse the level of irritation or the possible tourism-phobia that the residents in the historic centre feel due to the impact of tourism in the historic centre of Malaga. The secondary objectives proposed are:

O.1. The creation a specific scale to analyse tourism-phobia.

O.2. Sociodemographic analysis of residents in the study area and their relationship with tourism-phobia.

O.3. Analyse the spatial distribution of aspects relating to tourism-phobia.

The main contribution of this study is the measurement of tourism-phobia, as it is a notion that has not been sufficiently studied. It is the first study that proposes the measurement of this phenomenon via a statistically representative sample, as well as qualitative analysis.

\section{Theoretical context}

The debate around different concepts linked to the annoyance or irritation displayed by residents in tourist destinations is varied. This is due to the extensive terminological confusion around causes and processes. According to the Royal Spanish Academy (RAE), tourism is "the activity or action of travelling for pleasure" and phobia is "an exaggerated aversion to someone or something". Thus, it can be deduced that tourism-phobia is the fear, aversion or social rejection that people feel towards tourist activity.

The annoyance or irritation displayed by residents in tourist destinations is not a recent phenomenon, despite the fact that it may appear to be so, according to what the media depicts. The benchmark study in this field is the tourist irritation index created by Doxey (19759, subsequently this vision has been completed by other significant studies such as Butler's destination life cycle model (1980), which warned of the problems that a destination in its latter stages encounters, and thus, also its residents. Likewise, in the 70's Turner and Ash (1975) pointed out the cultural impact caused by tourism on host societies. In the decade of the 90's, mass tourism 
practices were condemned in different countries in southern Europe that were producing some protests (Boissevain, 1996).

In Spain, the first mention close to the concept of tourism-phobia was provided by Manuel Delgado through the term "tourist-phobia". Delgado (2007) defines this concept as a mix of scorn, distrust and contempt towards the figure that everyone calls "guiri" (slur applied to foreign tourists). He adds that he considers it to be "a kind of replacement xenophobia that is targeted at people who are not from here". The author draws attention to what he considers to be the main problem that is occurring in some destinations, "not the fact that there are tourists, but the fact there are only tourists". The tourism management of the historic centres is causing the emptying of people to make them spaces solely for business (Delgado, 2007). Donaire (2008) specifically mentions the term tourism-phobia, referring to the studies by Doxey (1975) to this end, and making this discontent coincide with the latter stages of this model. Donaire proposes a pragmatic approach to the term tourism-phobia based on the rational management, both of the flows of tourist mobility and the structures for receiving and accommodating tourists in cities.

Subsequently, Huete and Mantecón (2018) and Milano (2017, 2018) have linked tourism-phobia with a certain social opposition and criticism of tourist management. Milano (2017) describes that social criticism within a context of social organisations and residents outlining their disagreement with certain tourist activities. Huete and Mantecón (2018) coincides with Milano by pointing out that what the Spanish media considers to be tourism-phobia is essentially a social critique of certain aspects of tourism. Tourism is a very significant part of the capitalist system and the problems generated by tourism are part of the externalities that capitalism causes (Milano, 2018). The globalisation of economic activity results in the problems exported by tourism being localised in any destination around the world, especially in global cities and in iconic destinations. Milano (2018) criticises the fact that the media has given the term tourism-phobia a touch of media sensationalism and political exploitation which has concealed the grievances of associations in tourist destinations.

The discontent shown by residents in tourist destinations with a high level of intense tourist activity is repeated in these places: an increase in property prices, the privatisation of public spaces, a decrease in the purchasing power of residents, precarious employment in the tourism sector, the loss of traditional businesses, an imbalance between the number of residents and visitors, environmental impacts due to noise, waste, an increase in the offer of accommodation via online platforms, a significant increase in cruise ships, etc. These problems suffered by destinations are 
explained as a consequence of overcrowding, tourist saturation or overtourism, terms relating to the volume of visitors, and tourism-phobia is another derivative of the management problems of destinations (Milano, 2018).

Criticisms of tourism labelled as tourism-phobia by the media, are part of a shared phenomenon spread across numerous destinations, and not limited to Barcelona and Venice:

- Gentrification and touristification processes in Berlin (Füller \& Michel, 2014; Novy, 2016).

- Tensions due to socio-spatial transformations and touristification processes in the favelas of Rio de Janeiro (Broudehoux \& Sánchez, 2016).

- Social unrest in relation to housing dispossession and the processes of urban revaluation and touristification in the historic centre of Palma de Mallorca (Vives-Miró \& Rullan, 2017).

- The emerging discontent and irritation regarding overcrowding and socio-spatial transformations in the centre of Amsterdam (Gerritsma \& Vork, 2017; Pinkster \& Boterman, 2017).

- The emerging protest movements relating to the impacts of tourism in Paris, especially regarding the proliferation of tourist apartments (Gravari-Barbas \& Jacquot, 2016).

- The so-called Airbnb syndrome in the city of Reykjavík (Mermet, 2017).

- Protests against cruise ships and the increase in cruise passengers (Vianello, 2016) and the consultative referendum held in Venice.

- The protests of the people of Hong Kong against Chinese tourists (Garrett, 2016).

- The emergence of resistance regarding the use of land and local resources in Goa, India (Routledge, 2001).

The most striking example of the destination most affected by these problems is probably Venice, to such an extent that what happens in this historic city in relation to tourism has been called the "Venice Syndrome". This label emerged following the documentary "The Venice Syndrome" filmed in 2013 by the film director Andreas Pichler. The documentary outlines the main problems that the inhabitants of the city suffer in their daily lives. One of the greatest problems is the arrival of large cruise ships which have a serious social and environmental impact, in such a way that associations have been created against these vessels (Cominato no grandi navi-Laguna bene comunale), and it has exacerbated the problems already suffered by the city: severe depopulation, increased prices, pressure on cultural and natural resources, etc. (Troncoso, 2018). The fact that only $25 \%$ of visitors stay in the city is a sign of the strong pressure that the historic island is subjected to (Troncoso, 2018). Venice has become the most prominent example of a city being transformed into a theme park for tourism. 
On the other hand, some authors highlight the fact that there has not been much in-depth study of the process that leads to the irritation or annoyance of residents in tourist sites (Postma, 2013). In tourism research into this field, Doxey (1975) was pioneering by identifying the negative impacts that tourism brings with it within the community where it takes place; according to his research, the local population goes through five stages (euphoria, apathy, annoyance, antagonism and surrender) of behaviour caused by tourism. This study highlights the fact that to begin with tourists are welcomed in the destination, they even represent a positive development (euphoria), until in the interaction between the host and the visitor, a certain apathy or indifference begins to develop towards the visitors. Lastly, the latter two stages (antagonism and surrender) are where we could situate the tourism-phobia phenomena, as in these stages the residents begin to reject the excessive numbers of visitors and display irritation as a consequence of the reciprocal impacts between tourists and residents. Other authors reject Doxey's model of linear progression over time and point out that in the specific case of Barcelona, the attitudes of rejection and the factors that cause irritation among residents vary over time (Zerva, Palou, Blasco and Donaire, 2019).

Postma (2013) points out that there is a need for more detailed and deeper research about the factors that contribute to or specifically cause the development of this irritation, with the exception of the article by Doxey (1975) and the authors who cite him, or complemented his study, such as Murphy (1985), Fridgen (1991), Ryan (1991), Matthieson and Wall (1982), Wall and Mathieson (2006), Vanderwerf (2008) and Milligan (1989). Rátz and Puczkó (2002) tried to identify the factors that affect this irritation. For these authors, this attitude differs according to the specific characteristics of each tourist destination and the local community, and can develop in four dimensions: (i) according to the impacts that the population receives; (ii) in relation to the situation of the labour market and the social characteristics of the community; (iii) impacts at an individual and family level, and (iv) Impacts on natural and cultural resources. Subsequently, studies by Postma and Schmuecker (2017), identified ten areas of potential conflict that could lead to irritation and tourism-phobic behaviour by the local community. These authors point out everything from physical places (city centre, shops and museums) to behaviours, rejection or adaptation, the economic situation, conflicts between residents and tourists about the use of services, etc. The authors propose studying the phenomenon from the areas that cause overtourism.

Other authors (Alcalde, Guitart, Pitarch and Vallvé, 2018) highlight that the concept of tourismphobia has been used in a misguided way, confusing the social discontent due to too many tourists with the rejection of them. The authors themselves reject the idea that there is tourism-phobia in one of the centres most renowned for this phenomenon, Barcelona. They limit the discontent to the 
problems with coexistence and management of tourist activity. Others insist on finding out the factors that further encourage resilience among residents and make them more capable of adapting to the impacts of tourism, even in historic centres, such as in the study of Janusz, Six and Vanneste (2017) for the city of Bruges. A return to the analysis of the theory of social exchange is proposed, this theory has been extensively studied in research about the attitude of residents (Almeida, Balbuena and Cortés, 2015).

Simultaneously and as opposed to the concept of tourism-phobia, the term tourism-philia arises, which refers to the perception of the positive effects of tourism on the local economy and society (Zerva et al., 2019). This concept can be framed within the euphoria phase in the initial phase defined by the Doxey model (1975); in the later stages it can be associated with the discourse and actions carried out by tourism stakeholders that deal with potential positive aspects of tourism (Zerva et al., 2019). Likewise, on the other hand, the positive perception and the support to the tourist activity of the residents who are located at the opposite end of the tourism-phobic can be pointed out. This type of residents who, although aware of the negative aspects of tourism, mainly value the positive contribution in economic and social terms (Sharpley, 2014).

\section{Method}

\subsection{Study area}

The historic centre of Malaga that comprises the study area is identified with the ancient walled city of the Arabic era which was bounded to the east by the Guadalmedina River and to the south by the Mediterranean Sea. Along with this space, sections closer to the Arabic Medina have also been incorporated, to the north (Goleta, Ollerías, Plaza de la Merced Victoria and Lagunillas) and to the south (Soho and the Contemporary Art Centre, CAC), with the aim of evaluating if part of the tourist activities and their impact on residents has spread to them. In total, thirteen census sections have been selected which have a combined population that is not very high, in 2018 it was 13,874 inhabitants according to the figures of the census of inhabitants, who represent $2.4 \%$ of the total number of residents in the municipality of Malaga. The section with the largest population and the most residents in the area of La Goleta which had 2,226 inhabitants (INE, Spanish National Statistics Institute, 2019) (Table 1). The size of the study area is $2.03 \mathrm{~km}^{2}$ including the port, without including it, the area is $1.1 \mathrm{~km}^{2}$.

The most significant aspect of the population trend is the overall drop in residents, particularly the drop triggered in 2013 coinciding with the emergence of tourist properties in the city, since 2005 
the study area has lost 1,559 inhabitants. The only section that has managed to increase its population in relation to 2005 is La Goleta with an increase of 191 residents. In contrast, the adjoining section of Carretería is the one that has lost the most people with a total drop of 600 inhabitants (Figure 1).

Figure 1. Population trend in the study area

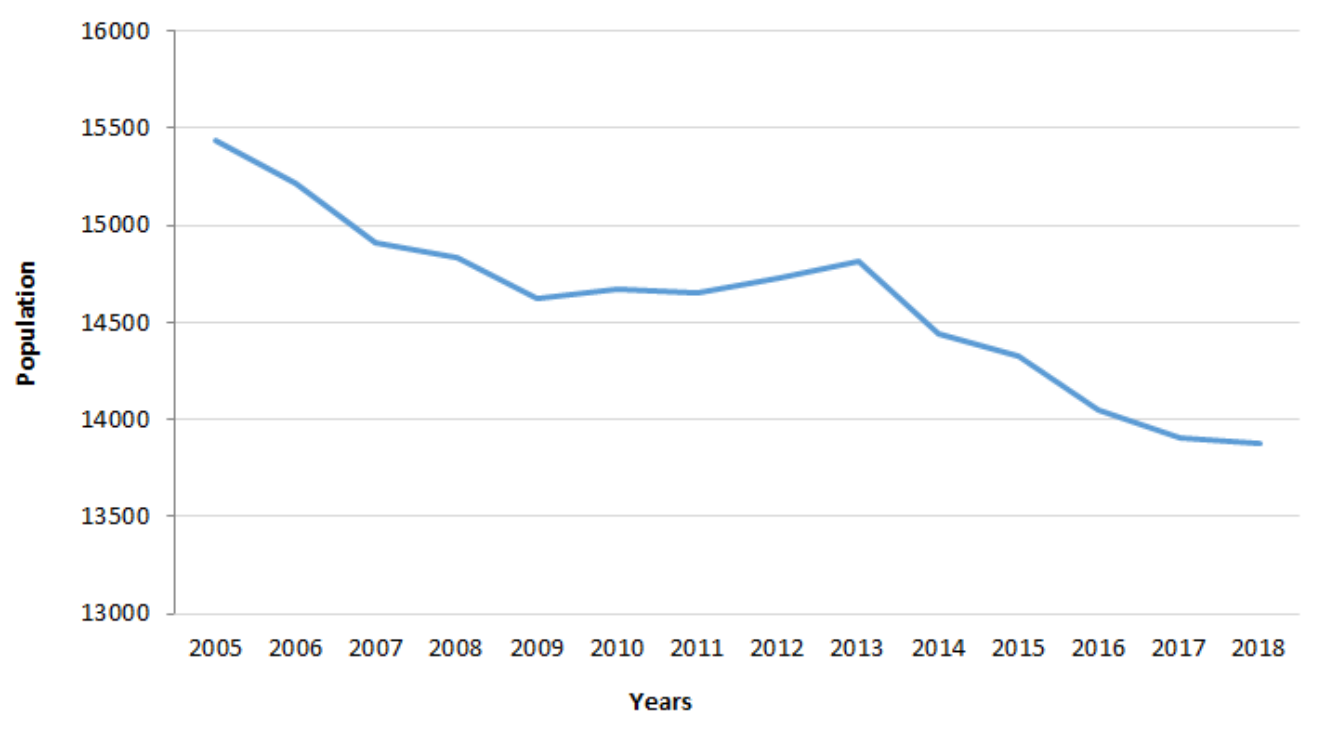

Source: prepared by the author based on INE (2019)

Figure 2. Distribution of tourist facilities in the study area

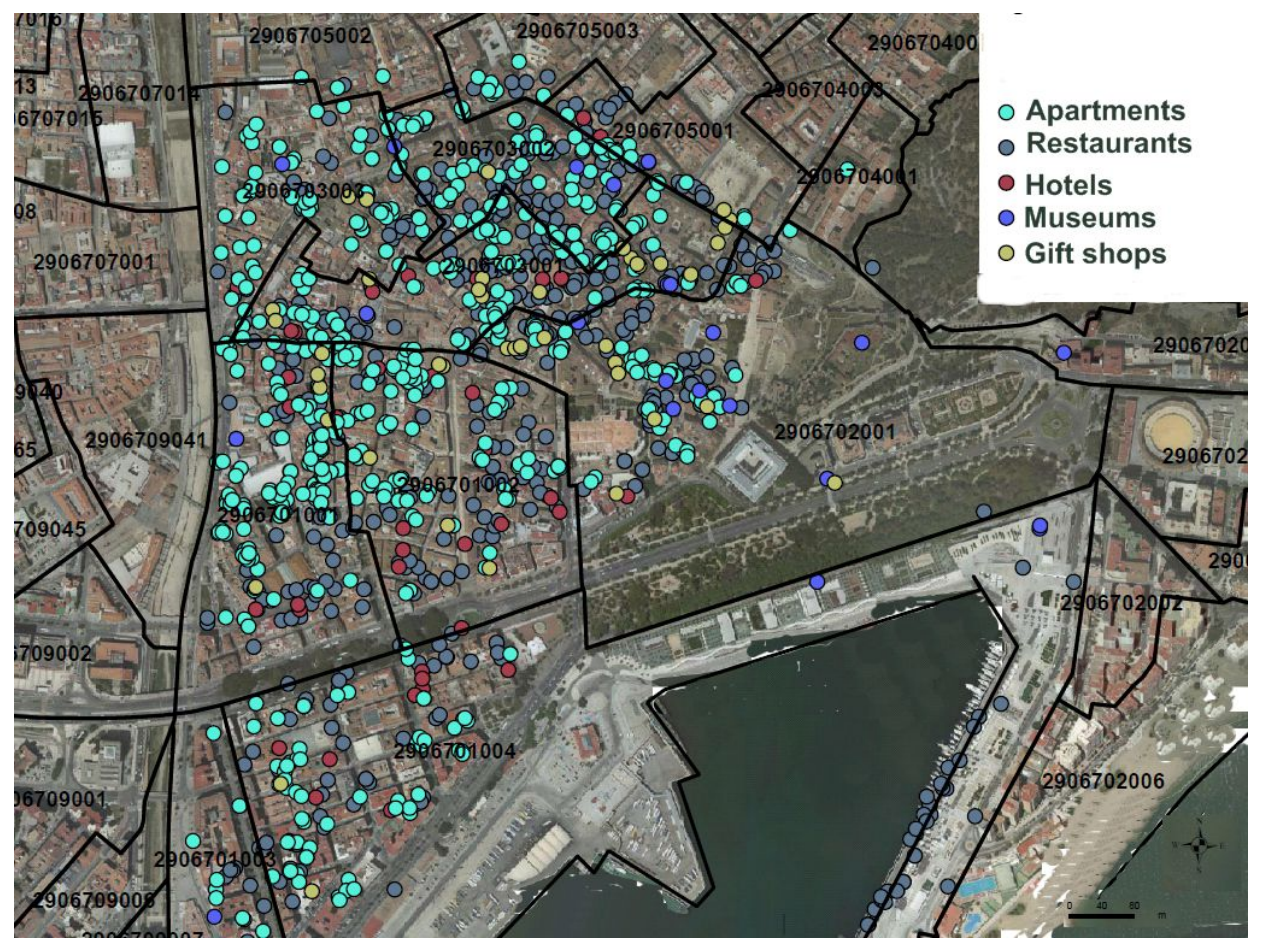

Source: own elaboration 
Table 1. Population trend by census sections (2005-2018)

\begin{tabular}{|c|c|c|c|c|c|c|c|c|c|}
\hline $\begin{array}{l}\text { Census sections/ } \\
\text { INE code }\end{array}$ & 2005 & 2010 & 2013 & 2014 & 2015 & 2016 & 2017 & 2018 & $\begin{array}{c}\text { Population } \\
\text { balance } \\
(2005- \\
2018)\end{array}$ \\
\hline $\begin{array}{l}\text { Atarazanas } \\
2906701001\end{array}$ & 1,296 & 1,145 & 1,148 & 1,147 & 1,127 & 1,129 & 1,162 & 1,122 & -174 \\
\hline $\begin{array}{l}\text { Larios } \\
2906701002\end{array}$ & 981 & 848 & 794 & 742 & 736 & 709 & 689 & 692 & -289 \\
\hline $\begin{array}{l}\text { Centro Arte Cont. } \\
2906701003\end{array}$ & 1,303 & 1,202 & 1,265 & 1,262 & 1,234 & 1,193 & 1,180 & 1,218 & -85 \\
\hline $\begin{array}{l}\text { Soho } \\
2906701004\end{array}$ & 1,393 & 1,286 & 1,276 & 1,242 & 1,238 & 1,247 & 1,222 & 1,248 & -145 \\
\hline $\begin{array}{l}\text { Catedral } \\
290670001\end{array}$ & 909 & 843 & 820 & 807 & 814 & 762 & 734 & 721 & -188 \\
\hline $\begin{array}{l}\text { Museo Thyssen } \\
2906703001\end{array}$ & 990 & 1.009 & 1.032 & 1.021 & 988 & 933 & 909 & 893 & -97 \\
\hline $\begin{array}{l}\text { Beatas } \\
2906703002\end{array}$ & 850 & 952 & 946 & 896 & 902 & 902 & 882 & 850 & 0 \\
\hline $\begin{array}{l}\text { Carretería } \\
2906703003\end{array}$ & 1,889 & 1,311 & 1,360 & 1,308 & 1,290 & 1,283 & 1,309 & 1,289 & -600 \\
\hline $\begin{array}{l}\text { Victoria/Lagunillas } \\
2906704003-5\end{array}$ & 2,036 & 1,970 & 2,127 & 2,061 & 2,053 & 2,012 & 1,982 & 1,957 & -79 \\
\hline $\begin{array}{ll}\text { Plaza de la } \\
\text { Merced } \\
290605001\end{array}$ & 838 & 915 & 871 & 834 & 823 & 800 & 754 & 765 & -73 \\
\hline $\begin{array}{l}\text { Goleta } \\
2906705002\end{array}$ & 2,035 & 2,248 & 2,218 & 2,205 & 2,194 & 2,183 & 2,193 & 2,226 & 191 \\
\hline $\begin{array}{l}\text { Ollerías } \\
2906705003\end{array}$ & 913 & 941 & 960 & 916 & 926 & 900 & 892 & 893 & -20 \\
\hline Total & 15,433 & 14,670 & 14,817 & 14,441 & 14,325 & 14,053 & 13,908 & 13,874 & $-1,559$ \\
\hline
\end{tabular}

Source: own elaboration

The study area concentrates a significant offer of the city's tourist offer, notably including 40 hotels and around 500 catering establishments (bars, restaurants and cafés) in addition to 1,085 properties for tourist accommodation which accounts for $39.6 \%$ of the total of the offer in the city of Malaga in April 2018 (RTA, 2019) (Andalusian Tourism Database). The Figure 2 shows the strong concentration of the accommodation offer that exists in the study area. The offer of tourist accommodation has continued to grow at a fast pace subsequent to the reference given.

\subsection{Analysis tools}

This study used both quantitative techniques in order to find out the degree of annoyance of residents as well as qualitative techniques in order to further examine the phenomenon of tourismphobia specifically and to understand how residents view the main impacts caused by the presence of tourists in the historic centre of Malaga. 
Quantitative technique. The questionnaire was the main tool for collecting information for its statistical treatment. Following the final wording of the survey, a pilot test was carried out which was applied to 35 residents in order to validate the tourism-phobia scale, a result of the good results the final study was carried out, which involved 378 respondents. The resulting sample was based on the population of the centre of Malaga in 2018, which had, according to the INE, (National Statistics Institute, 2019), a total of 13,016 residents. The participants were selected at random with a $5 \%$ margin of error and a confidence level of $95 \%$. A questionnaire was used which was administered directly in the street to the residents during the period between March and June 2018. The questionnaire consisted of three parts:

1. Sociodemographic aspects: gender, age, marital status, place of birth, level of education and job relating to tourism or not.

2. Tourism-phobia scale. A specific tourism-phobia scale was created in order to analyse the annoyance of the population in the study area. The scale is comprised of seven items: (i) I am annoyed by the dirt and bad smell in some streets due to tourism; (ii) I am annoyed by the noise caused by tourism; (iii) I am annoyed seeing tourists everywhere in the centre; (iv) I am annoyed by the bad behaviour of some tourists; (v) I am annoyed by tourists binge drinking; (vi) I am annoyed by so many cruise ships coming; (vii) I am annoyed by tourists in general. The level of annoyance of the population was measured using a five-point Likert scale for each item, where 1 equated to "not at all", 2 "a little", 3 "somewhat", 4 "yes a lot" and 5 indicated "yes, an awful lot".

3. Assessment by residents of aspects of urban space management. The scale is comprised of three items: (i) I am annoyed that that the centre of Malaga is becoming a space for tourists and not for residents; (ii) I am annoyed by the lack of Council regulation in the centre, and (iii) I am annoyed that the Council has not listened to the opinion of its residents for the regulation of the centre.

The data was processed using the statistical software SPSS version 23. Different analyses were carried out, firstly, a descriptive study of the sociodemographic data of the population, secondly, an ANOVA test and a post hoc (Scheffé) test were carried out in order to determine the groups of residents with different attitudes relating to tourism-phobia, and thirdly, the chi-squared test was applied for the analysis of the tourism-phobia scale in relation to sociodemographic variables and urban space management. 
- Qualitative technique. Ten interviews were carried out with residents of the centre of Malaga over the months from April to June in 2018. These people were identified through snowball sampling which consists of inviting participants to identify other subjects relating to the subject of study. This technique is normally used when you do not know the population that you wish to access. The size of the sample is small, but as the answers were repeated, it was considered that there were no new innovative answer patterns, they were saturated (Hernández et al., 1996), which resulted in the end of the process to look for new stakeholders. The profile of the interviewees is that of residents in the historic centre of Malaga, who showed annoyance with tourism; the first belonged to the association of residents of the historic centre of Malaga and Soho, these interviewees facilitated the contact of other residents in the area, who had no relationship with associations.

The ten interviews carried out were semi-structured. This format is an essential resource for capturing the reasons, meanings and opinions of the protagonists of the processes studied (Dunn, 2010). The questions relate to the existence of tourism-phobia among residents and the perception they have of tourism. The transcriptions of the interviews were analysed using the program ATLAS.ti., a tool that contributed to the reduction, coding, and organisation of data (Sabariego et al., 2014). The codes R.1, R.2 were established, ....in order to anonymously refer to the annoyed residents who agreed to the interviews. Two main categories of residents were identified (tourism-phobic -TPHOB- and tourism-philic -TPHIL- and two subcategories (impacts -1and tourism management $-M-)$.

- Cartographic representation. A thematic map was created of the aspects relating to the annoyance of the residents, generated for the residents who may display signs of tourismphobia. The scale of analysis used is the census section and its representation was carried out using the program QGIS. For the census section, the average value of each variable used to measure tourism-phobia has been represented, along with the average value of tourism-phobia recorded.

\section{Results}

\subsection{Descriptive statistics of the resident profiles in the study area}

In this study, the sample is formed by residents in the centre of Malaga. With regard to the gender of the resident population, the female population predominates with $57.7 \%$, the age group with the largest number of residents was 46 to 65 years, (43.7\%); with regard to marital status, the 
group of married residents (35.4\%) slightly stands out. Most of the residents were born in the city of Malaga (57.9\%). Those coming from the rest of Spain represent $24.3 \%$; another municipality in the province and another country amount to $6.9 \%$ and only $4 \%$ were born somewhere else in Europe. On the other hand, the residents who have been living in the centre of Malaga for more than 11 years stand out $(61.1 \%)$ and were the majority of the sample.

One of the most significant aspects of the population surveyed is the predominance of the level of university studies (52.6\%), which is related to the work profile of the population residing in the area, mainly liberal professionals. $70.9 \%$ of the respondents have not had or do not have a job relating to tourism, almost a quarter $(24.1 \%$ ) have been linked to the tourist sector and only $5 \%$ were linked to it at some point.

In the descriptive profile of the sample, a higher level of participation of women than men was obtained. The average age is around the age group of 46-65 years. The majority of these residents live with somebody, (married or with their partner), they were born in the city of Malaga, and have lived in the study area for more than eleven years. The majority are university educated, therefore they have a high level of education and their work is not linked to the tourist sector (Table 2).

Table 2. Resident profile

\begin{tabular}{|l|l|}
\hline & \multicolumn{1}{|c|}{ Predominant aspect } \\
\hline Gender & Women (57.7\%) \\
\hline Age & $46-65$ years (43.7\%) \\
\hline Marital status & Married and with a partner (49.7\%) \\
\hline Place of birth & City of Malaga (57.9\%) \\
\hline Length of residence & More than 11 years (61.1\%) \\
\hline Level of education & University educated (52.6\%) \\
\hline Work related to tourism & No (70.9\%) \\
\hline
\end{tabular}

Source: own elaboration

With regard to the analysis of the items that comprise the tourism-phobia scale, the residents of Malaga considered that the aspect that they find most annoying is binge drinking tourism with an average score of 4.35 out of 5 , in fact $84.9 \%$ of the respondents are annoyed a lot or an awful lot; secondly, the inhabitants complain about the dirt and the bad smell of some streets, with an average score of 3.87 out of 5 , with $72.2 \%$ very annoyed about it; and, in third place, they outline 
their discontent with the bad behaviour of some tourists, which obtains a score of 3.67 (62.7\% of the respondents). Lastly, the noise caused by tourism is pointed out by $50.5 \%$ and attains an average score of 3.15. These three components of the tourism-phobia scale are linked to aspects that have a direct impact on the coexistence between residents and tourist, and that have a more important effect on their daily lives. These annoying aspects caused by tourism contrast with the low level of irritation of residents towards the presence of tourists, which only has a score of 1.46 out of 5 , and is the lowest value recorded on the scale. A similar perception is shown in relation to cruise ship tourism, which attains a value of 1.86 . Therefore, the data seems to indicate that residents complain about some impacts caused by tourism such as noise, smells, bad behaviour and especially binge drinking tourism which goes hand in hand with the aforementioned aspects. In contrast, there are no complaints about tourists in general (Table 3).

Based on the scores that each survey respondent has in the corresponding items of the tourismphobia scale, the arithmetic mean aimed at evaluating the overall tourism-phobia has been extracted. From the results obtained, we could point out that the residents whose average score is over 4 have a significant level of annoyance in relation tourism and we could classify them as tourism-phobic; the percentage of residents that could be identified as such is $17.5 \%$, the profile of this group is characterised by a predominant age of between 46 and 65 years, single, born in Malaga, university educated and residing in the Victoria, Ollerías, Thyssen Museum and Beatas sections. At the completely opposite end are the residents who are not very annoyed by the presence of tourists (values between 1 and 2). This tourism-philic group is comprised by $22.2 \%$ of the respondents and the main difference in relation to the tourism-phobic residents is that it is formed by an older population with a significant presence of residents over the age of 65 years, widowers, who share sections with a high presence of tourism-phobic residents in the Thyssen Museum, Victoria and Lagunillas zones.

In the distribution by sections of the overall tourism-phobia represented in Figure 10. It can be seen that the section of Calle Larios stands out above the rest due to the high concentration of visitors in this central space, area where it is possible to access most of the tourism offer in the historic centre. Secondly, the sections of La Goleta, Carretería and Beatas stand out, where there is a high concentration of bars, restaurants and night-life venues which have a negative impact on the quality of life of some residents and thus there is a negative assessment of tourist activity. In this area live most of the residents of the historic centre. Thirdly, the southern zone of the historic centre, which includes Soho and the Barrio de las Artes, has a relatively low level of conflict, despite the fact it maintains a high percentage of the resident population. This area has been the location of an offer 
of accommodation and restaurants for people with greater purchasing power, which is generating little conflict. Also, residents have a very clear perception that tourism and the Council have decisively contributed to improving the neighbourhood.

Table 3. Tourism-phobia scale and

aspects relating to the urban management of the area

\begin{tabular}{|c|c|c|c|c|}
\hline & $\begin{array}{l}\text { No / A } \\
\text { little }\end{array}$ & Somewhat & $\begin{array}{l}\text { Yes, a lot } \\
\text { and an } \\
\text { awful lot }\end{array}$ & Average \\
\hline & $1-2(\%)$ & $3(\%)$ & $4-5(\%)$ & $\begin{array}{l}\text { Item } \\
\text { average }\end{array}$ \\
\hline $\begin{array}{l}\text { I am annoyed by the dirt and bad smell in } \\
\text { some streets due to tourism }\end{array}$ & 19.1 & 8.7 & 72.2 & 3.87 \\
\hline I am annoyed by the noise caused by tourism & 36.0 & 13.5 & 50.5 & 3.15 \\
\hline $\begin{array}{l}\text { I am annoyed seeing tourists everywhere in the } \\
\text { centre }\end{array}$ & 63.0 & 15.6 & 21.4 & 2.16 \\
\hline $\begin{array}{l}\text { I am annoyed by the bad behaviour of some } \\
\text { tourists }\end{array}$ & 24.1 & 13.2 & 62.7 & 3.62 \\
\hline I am annoyed by tourists binge drinking & 8.8 & 6.3 & 84.9 & 4.35 \\
\hline I am annoyed by so many cruise ships coming & 72.2 & 12.7 & 15.1 & 1.86 \\
\hline I am annoyed by tourists in general & 85.5 & 9.0 & 5.5 & 1.46 \\
\hline Tourism-phobia average & 22.2 & 60.3 & 17.5 & 2.92 \\
\hline $\begin{array}{l}\text { I am annoyed by the lack of Council regulation } \\
\text { in centre }\end{array}$ & 22.7 & 13.0 & 64.3 & 3.69 \\
\hline $\begin{array}{l}\text { I am annoyed the Council doesn't listen to } \\
\text { opinion of residents }\end{array}$ & 18.3 & 9.5 & 72.2 & 3.93 \\
\hline $\begin{array}{l}\text { I am annoyed that the centre is becoming a } \\
\text { space for tourists }\end{array}$ & 25.1 & 13.5 & 61.4 & 3.62 \\
\hline
\end{tabular}

Source: own elaboration

The thematic cartography elaborated by sections (Figures 3-9) spatially located the variables analysed, corresponding to the scale of tourism phobia. Significant differences are observed in the north zone, Larios street and south zone. Subsequently, these variables are studied in section 4.3. 
Figure 3. Distribution by sections of tourism-phobia due to the dirt and bad smell in some streets due to tourism

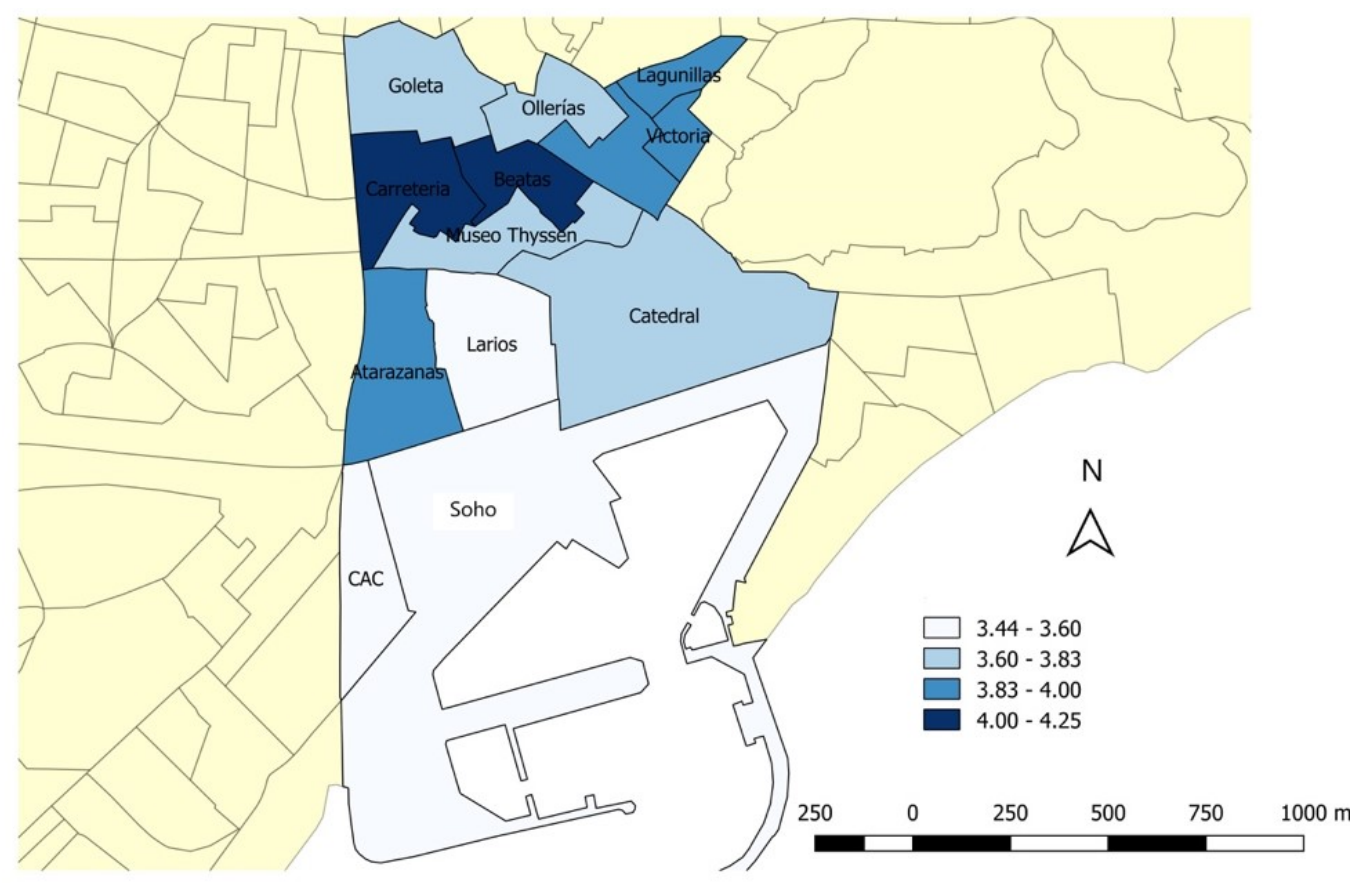

Source: own elaboration

Figure 4. Distribution by sections of tourism-phobia due to the noise caused by tourism

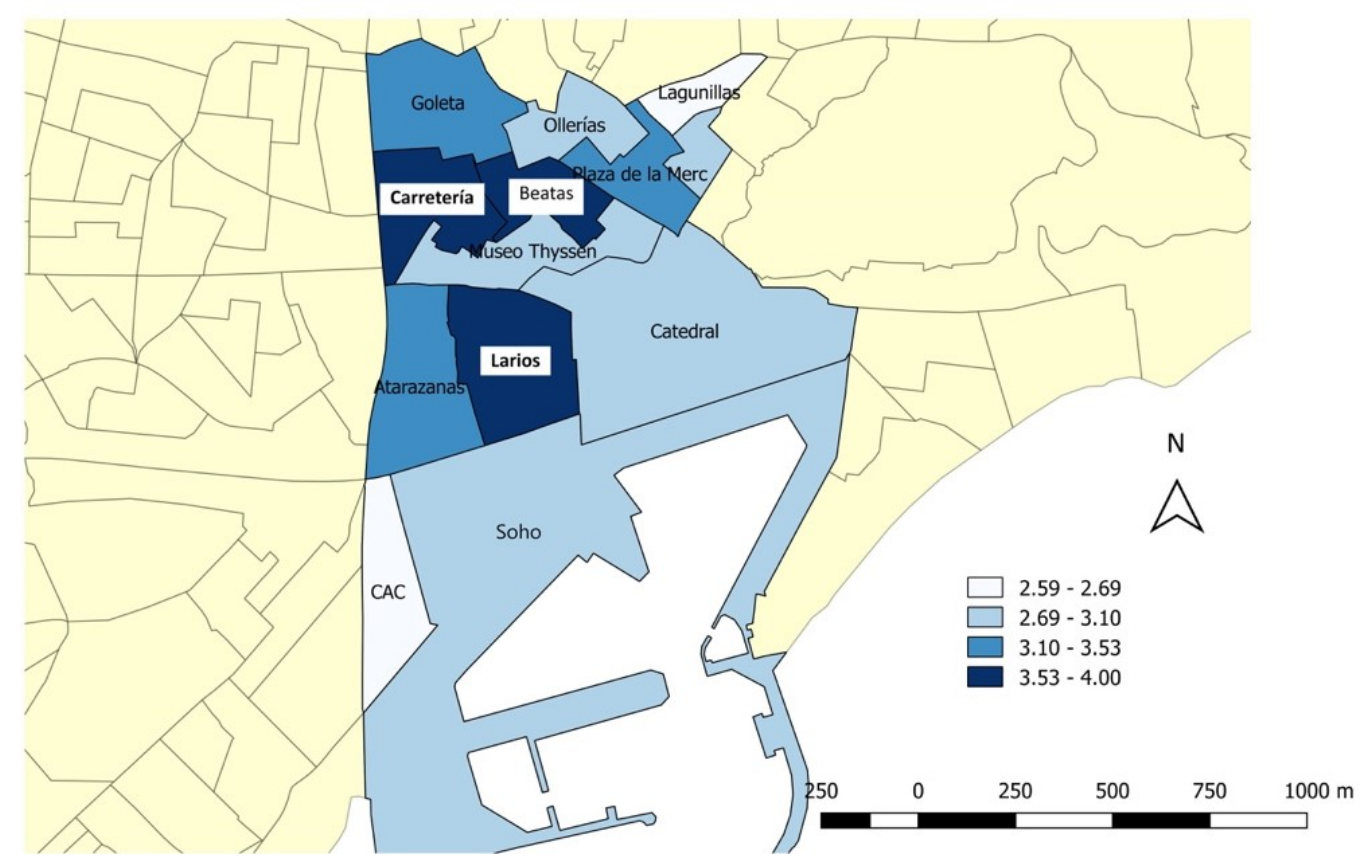

Source: own elaboration 
Figure 5. Distribution by sections of tourism-phobia due to seeing tourists everywhere

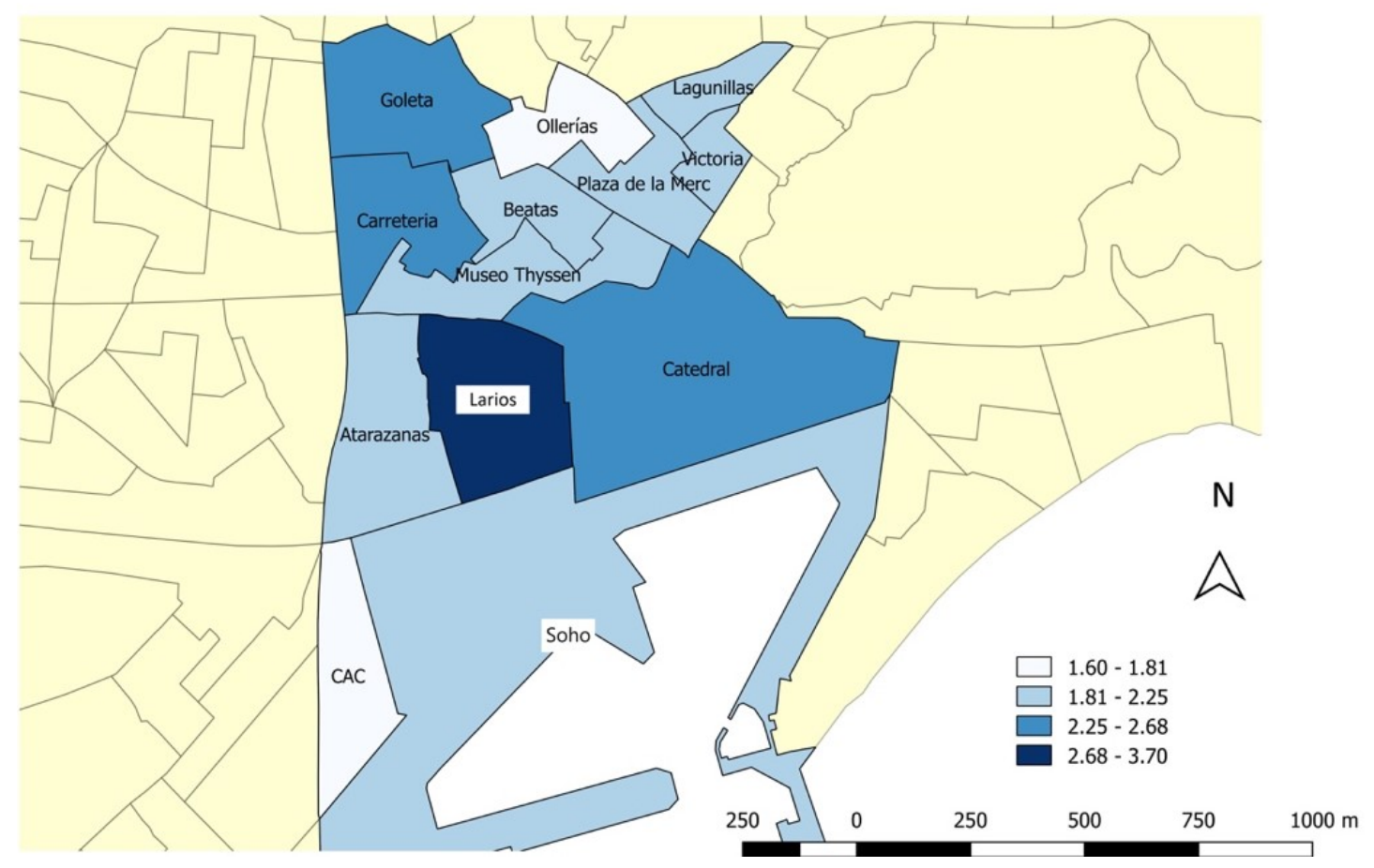

Source: own elaboration

Figure 6. Distribution by sections of tourism-phobia due to the bad behaviour of some tourists

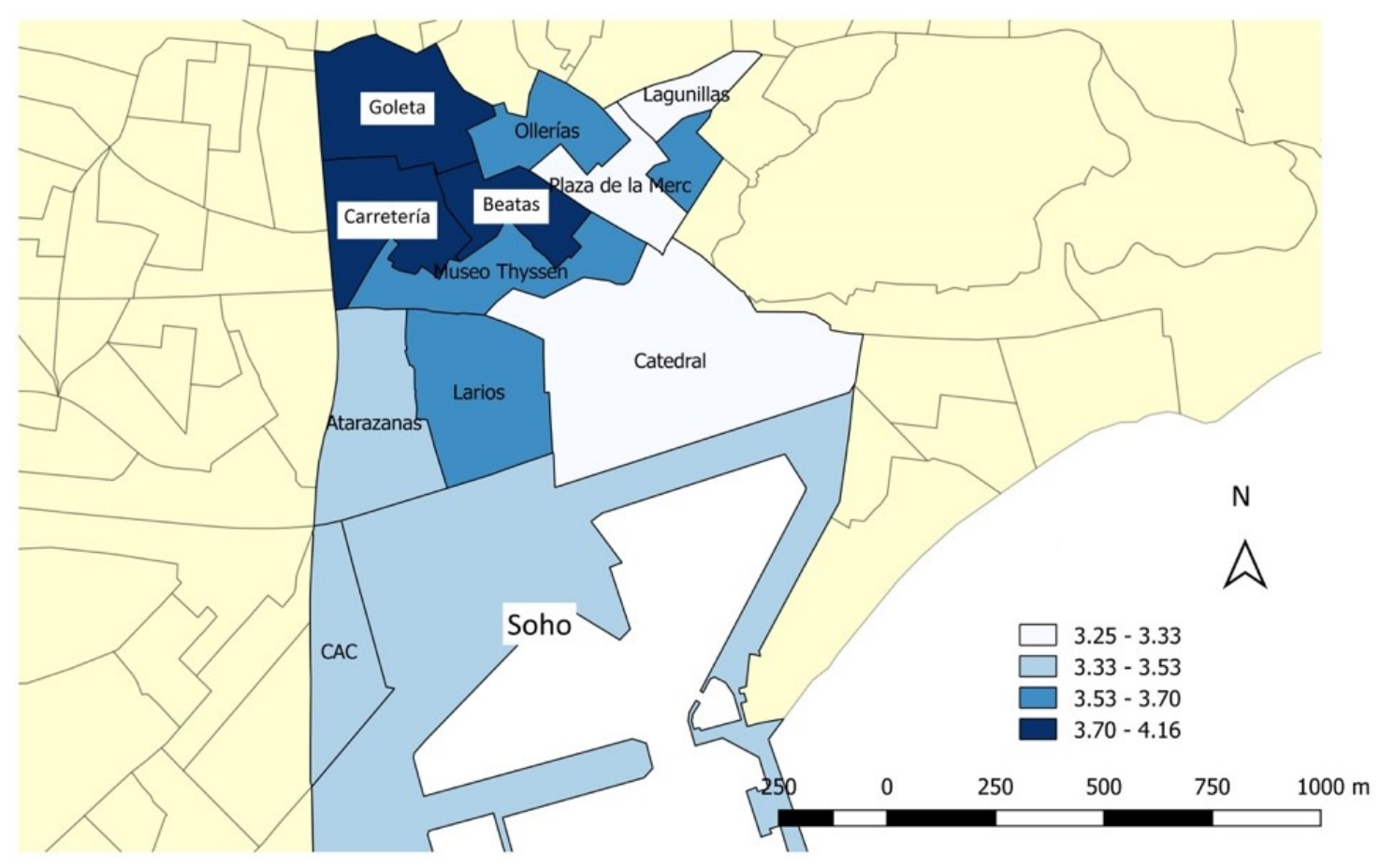

Source: own elaboration 
Figure 7. Distribution by sections of tourism-phobia due to binge drinking tourists

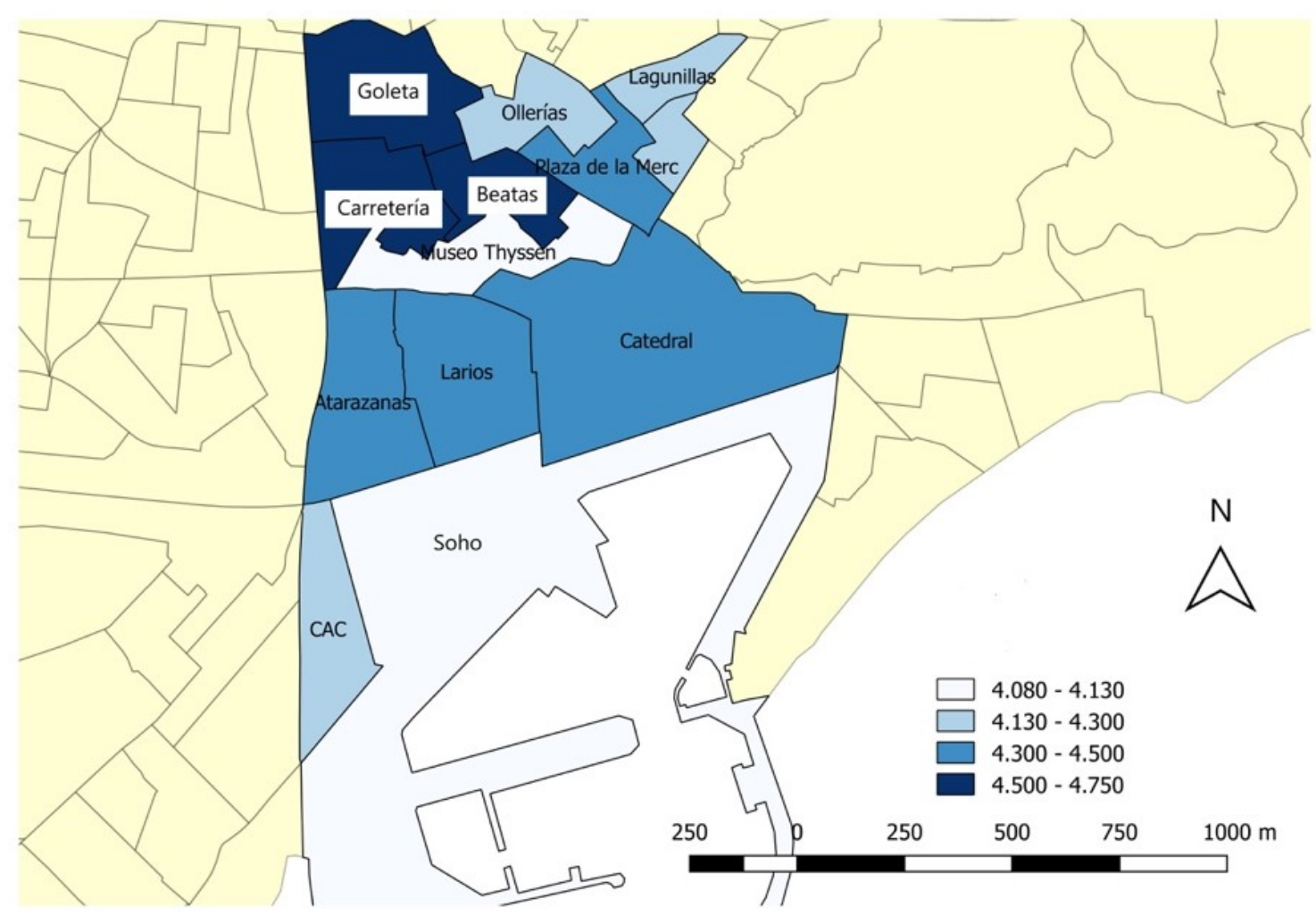

Source: own elaboration

Figure 8. Distribution by sections of tourism-phobia due to cruise ships

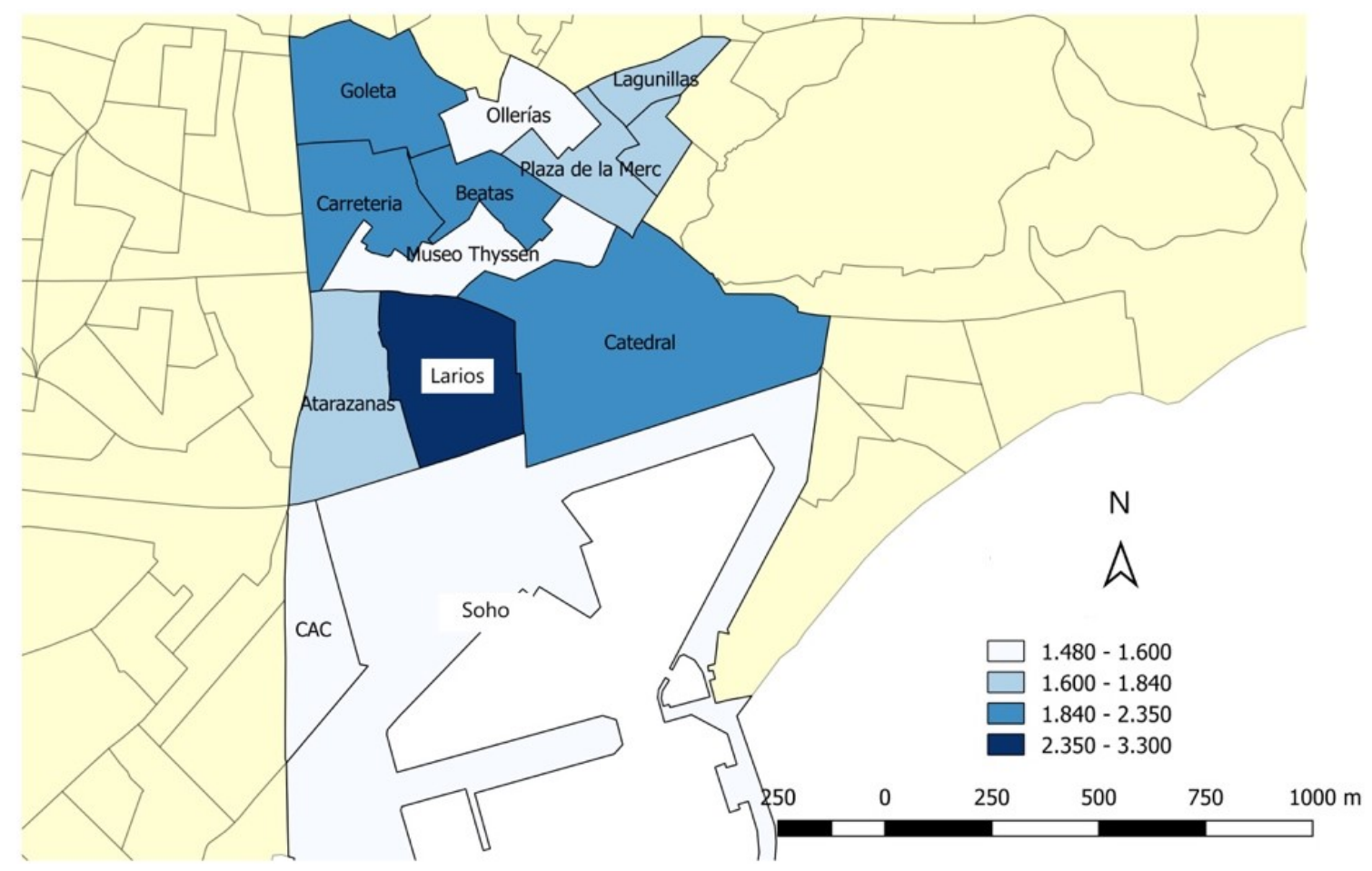

Source: own elaboration 
Figure 9. Distribution by sections of tourism-phobia due to tourists in general

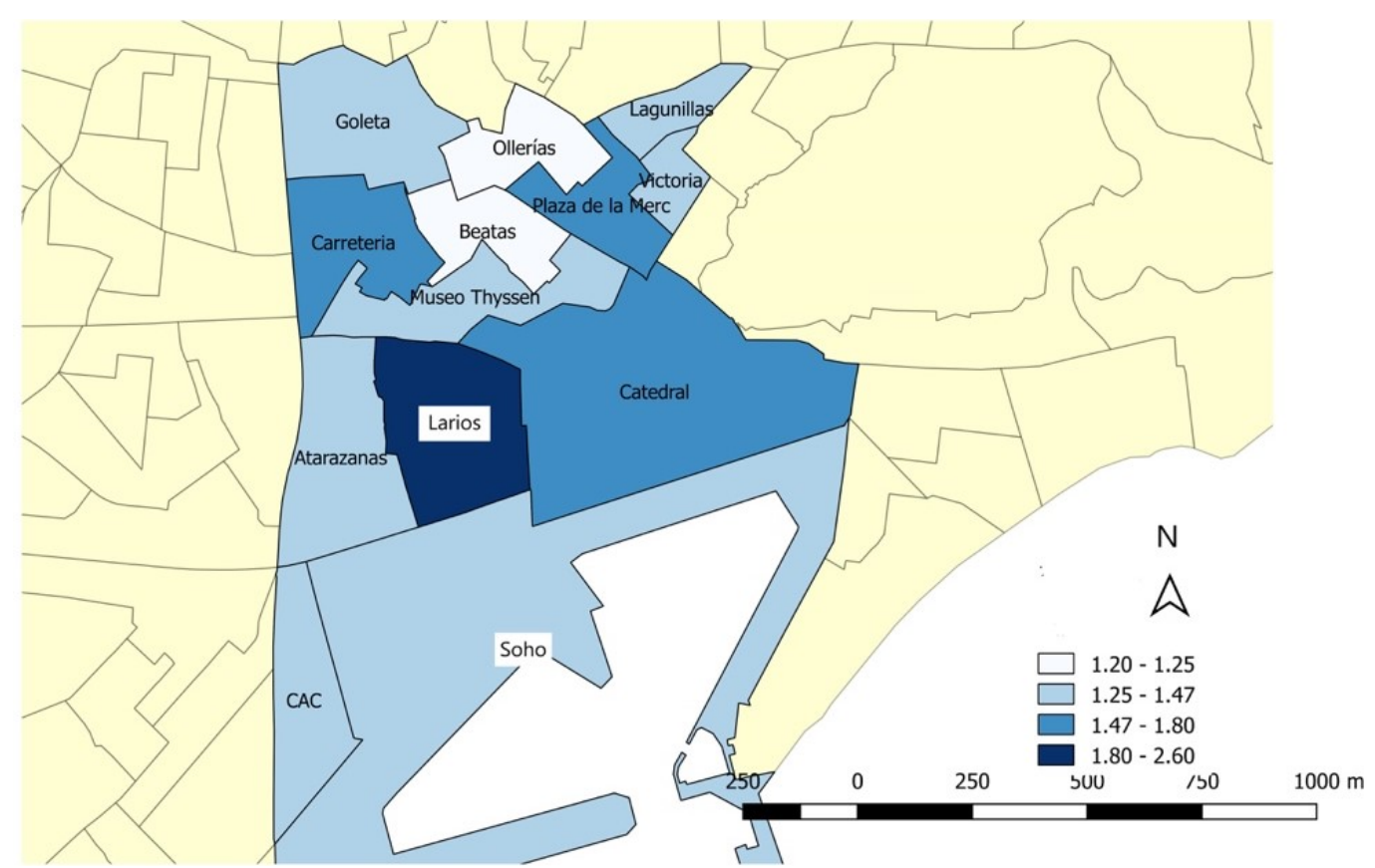

Source: own elaboration

Figure 10. Distribution by sections of Tourism-phobia in general

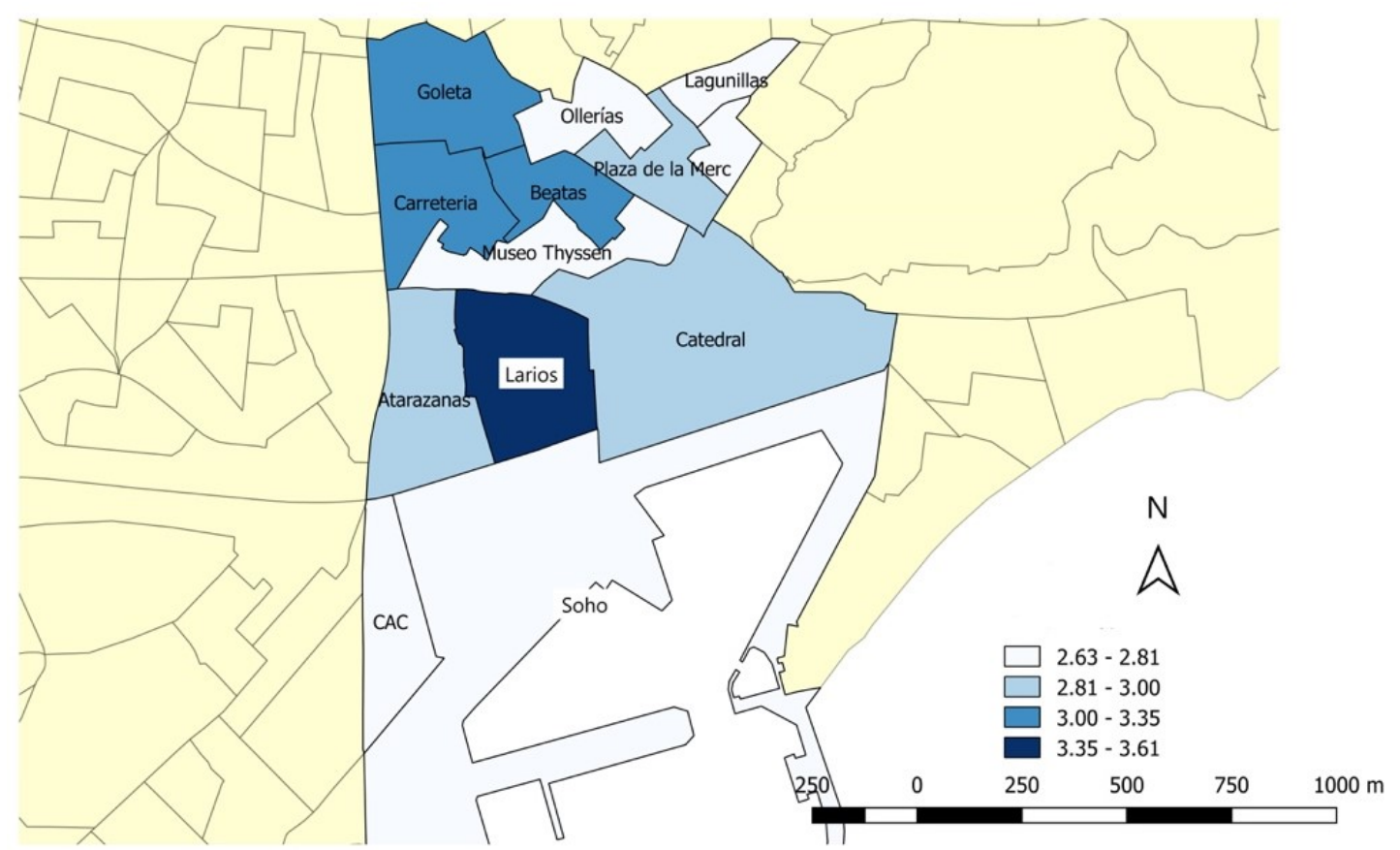

Source: own elaboration

\subsection{Analysis of variance: sociodemographic variables and tourism-phobia}

After the descriptive analysis of resident profiles, variance analysis was carried out in order to find out the different behaviour in relation to tourism and tourism-phobia among the two groups that display different attitudes: those who are very annoyed by activity and the others who are not 
annoyed at all by tourist activity (Table 4). The main statistics provided by the analysis of variance according to sociodemographic aspects are as follows:

Age: significant differences were found between age groups, with the $F$ value found to be $F=6.253$ corresponding to a value $(p=0.000)$. The post hoc test (Scheffé) determines that all the age groups (from 18-35 years, $p=0.011$; from 36-45, $p=0.028$; and from 46-65 years, $p=0.001$ ) feel greater annoyance in comparison to those over the age of 66.

Marital status: there are significant differences between groups with regard to marital status, $F=3.908$ corresponding to a value $(p=0.004)$. The post hoc test (Scheffé) determines that single people and those living with their partner $(p=0.038$ and $p=0.010$ respectively) feel a higher level of annoyance than widowers.

Level of education: a significant link was found between the level of education and tourism-phobia; $F=9.332$ corresponding to a value $(p=0.000)$. The post hoc test (Scheffé) determines that those who have primary studies feel much less annoyed than those who are university educated $(p=0.000)$.

No significant differences were found with the other variables: gender, place of birth and length of residence.

Table 4. ANOVA Results Tourism-phobia profile

\begin{tabular}{|l|l|}
\hline \multicolumn{1}{|c|}{ Less annoyed } & \multicolumn{1}{c|}{ More annoyed } \\
\hline People aged over 66 & Those aged 18-35; 36-45 and 46 to 65 \\
\hline Widowers/widows & Single people and those living with a partner \\
\hline Primary studies & University studies \\
\hline
\end{tabular}

Source: own elaboration

\subsection{Results of the analysis of the tourism-phobia scale}

In order to implement the objective of analysing the level of irritation and the possible tourismphobia of residents, the chi-squared test was applied to the tourism-phobia scale in relation to the sociodemographic variables and urban space management in order to determine the interdependency between them (Table 5). 
Table 5. Significant results of the chi-squared test

\begin{tabular}{|l|c|c|c|}
\cline { 2 - 4 } \multicolumn{1}{c|}{} & Value & df & $\begin{array}{c}\text { Asymptotic significance } \\
\text { (two-sided) }\end{array}$ \\
\hline Age * Dirt due to tourism & 31.711 & 12 & .002 \\
\hline Marital status * Noise due to tourism & 33.852 & 16 & .005 \\
\hline Level of education * Noise due to tourism & 33.570 & 12 & .001 \\
\hline Level of education * Bad behaviour & 38.220 & 12 & .000 \\
\hline Age * Binge drinking tourism & 27.785 & 12 & .000 \\
\hline Place of residence * Tourists everywhere & 729.993 & 628 & .003 \\
\hline Place of residence * Cruise ships & 733.367 & 628 & .002 \\
\hline Place of residence * Tourists in general & 806.717 & 628 & .000 \\
\hline
\end{tabular}

Source: own elaboration

The analysis results of the tourism-phobia scale in relation to the sociodemographic variables shows that there are essentially four most significant factors: place of residence, age, level of education and marital status. The most explanatory sociodemographic variable is the place of residence within the study area. The questions on the tourism-phobia scale that are most linked to the sociodemographic variables are: the presence of tourists everywhere, cruise ship tourism and tourism in general. With regard to the significance of the place of residence variable, it is due to the fact that the spatial distribution of tourists in historic centres is uneven and tourists tend to concentrate in very specific areas, therefore perceptions of them as something negative can vary significantly between the different areas of the city. In the case of the city of Malaga, as shown in the maps (Figures 3-10), the section that shows the highest values in these categories is the Larios section, which corresponds to the most visited area in the city. It is also necessary to highlight the presence of high levels of tourism-phobia in areas of the centre that are not very close to the Larios area, notably including La Goleta, one of the areas with the largest population, where the presence of tourists has not been very common and the tourism-phobic attitude may be mainly caused by the emergence of tourism accommodation in these areas and the generation of conflicts that affect coexistence and the daily life of its residents.

On the other hand, other aspects relating to the perception of the impacts caused by the behaviour of tourists such as dirt and smells, noise, bad behaviour and binge drinking tourism show differences relating to age, marital status and level of education. It is possible to point out that the 
population aged between 46 and 65 is that which has the most negative perception of the dirt and bad smells generated by tourism and binge drinking tourism, while the level of education, highlights that university educated and married residents have a more negative perception of the behaviour of tourists and noise.

Lastly, as mentioned previously, the chi-squared test was also carried out for the tourism-phobia scale in relation to the management variables included in the questionnaire (Table 6). In this case, it was about evaluating where the overall tourism of residents, quantified as the average of the different items, showed significant differences in relation to the assessment of the tourism management of the Council. The result shows that the three questions show significant differences, therefore residents with a greater degree of tourism-phobia view tourism management of the historic centre as the main cause of their discontent and acknowledge that if tourism were regulated more adequately, their attitude towards tourists could improve.

Table 6. Results of the chi-squared tests:

Overall tourism-phobia/Tourist management

\begin{tabular}{|l|c|c|c|}
\cline { 2 - 4 } \multicolumn{1}{c|}{} & Value & df & $\begin{array}{c}\text { Asymptotic significance } \\
\text { (two-sided) }\end{array}$ \\
\hline $\begin{array}{l}\text { I am annoyed that the centre of Malaga is becoming a space } \\
\text { for tourists and not for residents }\end{array}$ & 308.248 & 108 & .000 \\
\hline I am annoyed by the lack of Council regulation in the centre & 267.328 & 08 & .000 \\
\hline I am annoyed by the lack of Council regulation in the centre & 253.034 & 108 & .000 \\
\hline
\end{tabular}

Source: own elaboration

\subsection{Qualitative results}

With regard to the residents interviewed, three are men and seven are women. All are residents of Malaga who have lived in the centre of Malaga for years, they are university educated, over the age of 36, own a flat on a street in the tourism centre of Malaga and do not have any flats allocated for tourist use.

When the issue of tourism-phobia is approached, the residents have a very clear response, they are generally in favour of tourists and tourism because they value its contribution to improving the city's economy, what they view negatively are some aspects of tourism or types of tourists, as outlined in the following responses: 
"We have nothing against tourism, we have always experienced it, we have a tradition of tourism that we have grown up with, it has nothing to do with tourism, we want family tourism, cultural people, normal people and to attract it, don't build over me or offer low-cost seats" (R.6) (TPHIL-M).

"The people of Malaga and residents, we like tourism. The people of Malaga have always made a living from tourism and what we don't like and what affects us is overcrowding, there are people who come and cannot enjoy anything because there are too many people in the street, they don't even enjoy the city. We don't reject tourists at all, we are tourists too when we visit another place, I love travelling, perhaps we need to think about another type of tourism, tourism that is integrated, that respects the traditions of the place it goes to" (R. 2) (TPHIL-I).

"I cannot refuse the tourist, at all, I like the tourist who behaves well, I do not want Malaga to become a theme park" (R.9) (TFOB-M).

Among the interviewees there is only tree residents who do think that there may be tourism-phobia among the residents of the historic centre:

"I think that tourism-phobia is indeed being created naturally, a) because we do not at all like the type of tourism that is arriving, b) saturation results in a staggering drop in the quality of life, and c) those of us who are owners are seeing that our homes are worth money if you leave it" (R.4) (TPHOB-M).

"It is happening that we will have tourism phobia, there will be no choice, because it is logical, this type of tourism does not create a job, and the ones it generates are precarious, very badly paid. This type of mass tourism does not benefit us and needs more control. Also, does this tourism benefit? To the catering industry ..., I don't know who benefits". (R.9) (TPHOB-M).

"Mass tourism is rejected, tourism that bothers. I believe that a tourism phobia is being created, as a disease, since you cannot walk in the streets, you cannot live in peace" (R10) (TPHOB-I).

It is also necessary to highlight that there are residents who are annoyed when they are called tourism-phobic and don't understand why this name is used to designate a state of annoyance:

"We are called tourism-phobic but I view it as an insult to be called that because I am not, I have spent my entire life here, I grew up in Malaga and happily respected guiris 
(foreigners) and I am called that because I complain, but it isn't due to the guiris that come, the problem is the overcrowding, it is when there are so many tourist properties and you can't go down a street because there is a continuous stream of guiris coming and going, the problem is that the entire historic centre is at the service of tourists and the tourists who come are not the type we wanted to attract two years ago. If this is the city model they want, they should explain it to us (R.5) (TPHIL-M).

The residents have outlined their concern with the city model that is being created and above all, they fear that Malaga could become a city like Magaluf:

"What happens in Magaluf is already happening here and progressing" (R.6) (TPHIL-M).

"The situation in Magaluf is already here, we have videos recorded of groups of 15 guys that arrive drunk, urinating in the street and shouting the whole time. What happens is that we have this idea that when me talk about the centre we mean Calle Larios and as it doesn't happen there, it doesn't happen anywhere" (R.6) (TPHIL-M).

"We have adapted to the Magaluf model and that is not a slogan, we are already seeing that, the other day I counted seven stag parties during a walk around the centre, why, because there are cities that are limiting them and they are coming to Malaga" (R.4) (TPHOB-I).

Regarding whether tourism is responsible for their problems, all the residents point to one responsible party, the Administration or the Council and its poor management, or breach of existing legislation.

"I don't feel represented by the Council, they think more about the revenue they receive than the residents. There is no planning or control in relation to tourism by the authorities" (R. 1) (TPHOB-M).

"I think that it is totally responsible, totally responsible for the good and bad, Malaga has changed a great deal due to the council, t has carried out a lot of projects in the city in big areas such as the port, but it is responsible for not being able to control the imbalances that are being created" (R.2) (TPHIL-M).

"Tourism isn't the cause of the problem, it is the council. Don't bring more people than you are able to control. I am not against tourists but rather the poor management of the council and the arrival of binge drinking tourism, and the fact that there are no rules or they are not enforced" (R.3) (TPHIL-M). 
"An administration that doesn't get involved at street level and that does nothing, is no use to me" (R.6) (TPHIL-M).

"I am not against tourism, I am against chaos, tourism is another source of revenue, but I am against it being the only source of revenue. What happens is that that the Council doesn't comply with the by-laws on anything" (R.7) (TPHIL-M).

"Tourism is not controlled, ... it is emerging a rejection of tourism; tourism is not controlled by the City Council, it is a low quality tourism that does not provide benefits or provides few benefits" (R.9) (TFOB-M).

\section{Conclusions}

The historic centre of Malaga, just like what has happened in many cities, has experienced significant tourism growth encouraged by the different actions aimed at promoting the city as a destination for cultural tourism and due to the proliferation in recent years of an increasing offer of tourist accommodation. These transformations have caused a series of tensions between tourists and residents that had not been experienced thus far and which have been called tourism-phobia, in line with what other authors have identified (Milano, 2018; Huete \& Mantecón, 2018).

In the historic centre of Malaga, the presence of two groups of residents with clear and opposing attitudes towards tourism can be seen: tourism-phobic and tourism-philic. These two groups differ according to age, marital status and level of education and indicate one of the social transformations that the historic centre has undergone. The tourism-philic group represents the traditional population who have lived in the area for a long period of their lives. They are an ageing population, with little education, comprised of a high percentage of widows and widowers, pensioners, who despite the inconvenience caused by tourism, are more concerned about other effects such as gentrification (the disappearance of traditional trade and their old neighbours, the occupancy of public spaces, among other aspects). On the contrary, tourism-phobia is represented by middle-aged people, who live with their partners and have received higher education; they are liberal professionals who have chosen to live here because they appreciate the cultural value of the historic centre and have no professional relationship with tourism. The majority made this choice before the great tourism growth of the historic centre, therefore they have a very negative view of the change. This is the only population that has come to cover the disappearance of residents in this area, as the increased price of rental and property prices has, to a large extent, resulted in the residential emptying of this area. More than half of the residents are property owners. 
The tourism-phobic group is not the majority, but it is significant. This group is annoyed due to certain consequences of tourist activity that affect their daily lives such as binge drinking tourism, dirt and the bad smell of the streets and the bad behaviour of tourists, but the general irritation towards tourists is low. This statement coincides with comments gathered in interviews, in which the interviewees complain about the inadequate management of tourist activity. This situation is consistent with what has been outlined in other research that encompasses studies for other European destinations such as Barcelona, Amsterdam and Berlin (Alcalde et al., 2018) or Venice (Troncoso, 2018). Tourism-phobia is attributed to inadequate management of tourist activity or that is against residents (Milano, 2018; Troncoso, 2018), however other authors draw attention to the diversity of the origins of the problems that affect residents in tourist spaces and that converge in tourism (Mansilla, 2018). In the case of Malaga, some authors point out that over-tourism is the main element that affects the lives of residents and that there are numerous elements that fuel tourism pressure, mainly gentrification that empties the population of the area and public and private collaboration that transforms the urban space for an exclusive tourist activity (García, Barrera \& Scalici, 2019).

The residents interviewed point out that improper tourism management is attracting low-cost tourism, drunkenness, stag parties, which is one of the main causes of this discontent. On the other hand, residents outline their concern with the model of city that is being built, which seems to moving ever closer to the structure of Magaluf. Both the interviewees with tourism-phobic attitudes and tourism-philic attitudes, complain extensively about the deficient management by the Council of Malaga. This situation is in line with the responses given by the respondents in relation to questions about tourism management, who display considerable annoyance (Table 3).

The distribution of the perception of tourism-phobia is not homogeneous among the different census sections and the assessment by the residents is conditioned by the type of activity carried out by the visitors, their degree of concentration, the characteristics of the urban morphology, the presence of activities that generate a greater level of annoyance: binge drinking tourism, bad behaviour by the tourists, dirt and noise. In general, there is not a rejection of tourists, but rather rejection of some of their impacts, and residents do not view the presence of tourists or cruise passengers as something negative.

In short, what is named tourism-phobia seems to be a critique of the model of tourism management, rather than a criticism of tourists or tourism. Having said this, the existence of a group of residents who are quite irritated with tourism and tourists and the general discontent with tourism 
management by the Council, could result in a strong general protest movement towards tourist activity in the historic centre.

Acknowledgments: The research was supported by research projects: "Transformations of the historical urban landscape induced by tourism: contradictions and controversies, government and local governance" (CSO2016-75470-R); "Overtourism in Spanish coastal Destinations. Tourism degrowth strategies An approach from the social dimension "(RTI2018-094844-B-C33), Spanish Ministry of Science, Innovation and Universities (National Plan for R+D+i); and "Tourism phobia and Tourism filia in the city of Malaga", Research Plan of the University of Malaga, Spain.

Authorship statement: The authors declare no conflict of interest. The participation of the authors in the article is as follows. Fernando Almeida García: Literature review, statistical analysis and conclusions. Rafael Cortés Macías: Methodology, cartographic analysis and results. Antonia Balbuena Vázquez: Introduction, methodology and results. 


\section{References}

Alcalde, J., Guitart, N., Pitarch, A., \& Vallvé, O. (2018). De la turismofobia a la convivencia turística: el caso de Barcelona. Análisis comparativo con Ámsterdam y Berlín. Ara. Revista de Investigación en Turismo, 8(2), 25-34. Retrieved from http://revistes.ub.edu/index.php/ara/article/view/21980

Almeida, F., Balbuena, A., \& Cortes, R. (2015). Residents' attitudes towards the impacts of tourism. Tourism Management Perspectives, 13, 33-40. https://doi.org/10.1016/j.tmp.2014.11.0072

Baptista, L. (2005). Territórios lúdicos (e o que torna lúdico um território): Ensaiando um ponto de partida. In Actas dos ateliers do V Congresso Português de Sociologia. Sociedades Contemporâneas: Reflexividade e Acção Atelier: Cidades, Campos e Territórios. Lisboa. Retrieved from https://aps.pt/wp-content/uploads/2017/08/DPR461180e841edb_1.pdf

Boissevain, J. (Ed.). (1996). Coping with tourists: European reactions to mass tourism (Vol. 1). Berghahn Books.

Blázquez, M., \& Cañada, E. (2011). Turismo placebo: nueva colonización turística del Mediterráneo a Mesoamérica y el Caribe, lógicas espaciales del capital turístico. Managua: EDISA.

Bonilla, A., \& Mortd, M. (2008). Turismo y conflictos territoriales en el Pacífico de Nicaragua: el caso de Tola, más allá de los titulares. San Salvador: Fundación Prisma.

Broudehoux, A. M., \& Sánchez, F. (2016). The politics of mega-event planning in Rio de Janeiro: Contesting the Olympic city of exception. In V. Teoksessa, Viehoff \& G. Poynter (Eds.), Mega-event cities: Urban legacies of global sports events (pp. 109-119). London: Routledge.

Butler, R. W. (1980). The concept of a tourist area cycle of evolution: implications for management of resources. Canadian Geographer/Le Géographe canadien, 24(1), 5-12. Retrieved from hitp://www.numptynerd. net/uploads/1/2/0/6/12061984/butler_model_1980.pdf

Butler, R. W. (1999). Sustainable tourism: A state-of-the-art review. Tourism Geographies, 1(1), 725. https://doi.org/10.1080/14616689908721291

Cannonier, C., \& Galloway, B. (2018). The economic growth impact of tourism in Small Island Developing States-evidence from the Caribbean. Tourism Economics. 25(1), 85108. hitps://doi.org/10.1177/1354816618792792

Cañada, E. (2010). Turismo en Centroamérica: nuevo escenario de conflictividad. Managua: Enlace Editorial. 
Comerio, N., \& Strozzi, F. (2019). Tourism and its economic impact: A literature review using bibliometric tools. Tourism Economics, 25(1), 109-

131. https://doi.org/10.1177/1354816618793762

Delgado, M. (2007). Turistofobia. El País. Retrieved from https://elpais.com/diario/2008/07/12/catalunya/1215824840_850215.html

Donaire, J. A. (2008). La efervescencia de la "turismofobia". Barcelona Metrópolis. Revista de información y pensamiento urbanos, 72, 70-75. Retrieved from http://www.publicacions.ben.es/b_mm/bmm72/bmm72.pdf

Doxey, G. (1975). A causation theory of visitor-resident irritants, methodology and research inferences. The impact of tourism. Presented at the 6th Annual Conference of the Travel Research Association.

Fridgen, J. (1991). Dimensions of Tourism. East Lansing, MI: American Hotel and Motel Association Educational Institute.

Füller, H., \& Michel, B. (2014). 'Stop Being a Tourist!' New Dynamics of Urban Tourism in BerlinKreuzberg. International Journal of Urban and Regional Research, 38(4), 13041318. https://doi.org/10.1111/1468-2427.12124

García, S., Barrera, D., \& Scalici, M. (2019). Touristification in historic cities: Reflections on Malaga. Revista de Turismo Contemporâneo, 7(1), 93-115.

Garrett, D. (2016). Contesting China's tourism wave: identity politics, protest and the rise of the Hongkonger city state movement. In J. Colomb \& J. Nowy (Eds.), Protest and Resistance in the Tourist City (pp. 121-142). London: Routledge. https://doi.org/10.4324/9781315719306

Gerritsma, R., \& Vork, J. (2017). Amsterdam Residents and Their Attitude Towards Tourists and Tourism. Coactivity: Philosophy, Communication/Santalka: Filosofija, Komunikacija, 25(1), 8598. https://doi.org/10.3846/cpc.2017.274

Gravari-Barbas, M., \& Jacquot, S. (2016). No conflict? Discourses and management of tourismrelated tensions in Paris. In J. Colomb \& J. Nowy (Eds.), Protest and resitance in a tourist city (pp. 45-65). London: Routledge. https://doi.org/10.4324/9781315719306

Harrill, R. (2004). Residents' attitudes toward tourism development: A literature review with implications for tourism planning. Journal of planning literature, 18(3), 251266. https://doi.org/10.1177/0885412203260306 
Hiernaux, N. D. (1999). Cancun Bliss. In D. Judd \& S. Fainstein (Eds.), The Tourist City (pp. 124139). New Haven, CT: Yale University Press.

Huete, R., \& Mantecón, A. (2018). El auge de la turismofobia čhipótesis de investigación o ruido ideológico? Pasos. Revista de Turismo y Patrimonio Cultural, 16(1), 9-19. Retrieved from http://www.pasosonline.org/Publicados/16118/PS118_01.pdf

INE (Instituto Nacional de Estadística) (2019). Estadísticas del Padrón continuo. Retrieved from https://www.ine.es/dyngs/INEbase/es/operacion.htm?c=Estadistica_C\&cid=1254736177 $\underline{012 \& m e n u=u l t i D a t o s \& i d p=1254734710990}$

Janusz, K., Six, S., \& Vanneste, D. (2017). Building tourism-resilient communities by incorporating residents' perceptions? A photo-elicitation study of tourism development in Bruges. Journal of Tourism Futures, 3(2), 127-143. Retrieved from

https://www.emeraldinsight.com/doi/full/10.1108/JTF-04-2017-0011

Mansilla, J.A. (2018). Vecinos en peligro de extinción. Turismo urbano, movimientos sociales y exclusión socioespacial en Barcelona. Pasos. Revista de Turismo y Patrimonio Cultural, 16(2), 279286. Retrieved from: http://www.pasosonline.org/Publicados/16218/PS218_01.pdf

Mathieson, A., \& Wall, G. (1982). Tourism: Economic, Physical and Social Impacts. London: Longman.

Mermet, A. C. (2017). Airbnb and tourism gentrification: critical insights from the exploratory analysis of the 'Airbnb syndrome'in Reykjavik. In M. Gravari-Barbas \& S. Guiñándolos (Eds.), Tourism and Gentrification in Contemporary Metropolises (pp. 52-74). London: Routledge.

Milano, C. (2017, September 10). Turismofobia: cuando el turismo entra en la agenda de los movimientos sociales. In Marea urbana. Retrieved from https://mareaurbanabcn.wordpress.com/2017/04/25/turismofobia-cuando-el-turismoentra-en-la-agenda-de-los-movimientos-sociales/

Milano, C. (2018). Overtourism, malestar social y turismofobia. Un debate controvertido. Pasos. Revista de Turismo y Patrimonio Cultural, 16(3), 551-564. Retrieved from http://www.pasosonline.org/Publicados/16318/PS318_01.pdf

Milligan, J. (1989). Migrant workers in the Guernsey hotel industry. Unpublished thesis, Nottingham Business School, Nottingham Polytechnic. In C. Ryan, Recreational Tourism. A Social Science Perspective. London: Routledge. 
Murphy, P. E. (1985). Tourism: A community approach. London: Methuen.

Novy, J. (2016). The selling (out) of Berlin and the de- and re-politicization of urban tourism in Europe's 'Capital of Cool'. In J. Colomb \& J. Nowy (Eds.), Protest and resistance in a tourist city. London: Routledge. https://doi.org/10.4324/9781315719306

Pinkster, F. M., \& Boterman, W. R. (2017). When the spell is broken: gentrification, urban tourism and privileged discontent in the Amsterdam canal district. Cultural geographies, 24(3), 457472. hitps://doi.org/10.1177\%2F1474474017706176

Postma, A. (2013). 'When the tourists flew in'. Critical encounters in the development of tourism (Doctoral dissertation, University of Groningen, Netherlands). Retrieved from https://www.rug.nl/research/portal/publications/pub/052532b5-d59f-4dbe-84593af3ce1fe404).html

Postma, A., \& Schmuecker, D. (2017). Understanding and overcoming negative impacts of tourism in city destinations: conceptual model and strategic framework. Journal of Tourism Futures, 3(2), 144-156. Retrieved from: https://www.emeraldinsight.com/doi/full/10.1108/JTF-04-2017$\underline{0022}$

RAE (Real Academia Española) (2019). Retrieved from http://www.rae.es/

Rátz, T., \& Puczkó, L. (2002). The impacts of Tourism: An Introduction. Hämeenlinna: Hame Polytecnic.

Richards, G., \& Hall, D. (Eds.). (2003). Tourism and sustainable community development (Vol.7). London: Routledge.

Rivera, M., \& Rodríguez, L. (Coord.), (2012). Turismo responsable, sostenibilidad y desarrollo local comunitario. Universidad de Córdoba. Retrieved from

htps://dialnet.unirioja.es/servlet/libro?codigo=525510

Routledge, P. (2001). 'Selling the rain', resisting the sale: Resistant identities and the conflict over tourism in Goa. Social \& Cultural Geography, 2(2), 221240. https://doi.org/10.1080/14649360120047823

RTA (Andalusian Tourism Database) (2019). Consejería de Turismo y Deportes, Junta de Andalucía. Retrieved from

http://www.juntadeandalucia.es/turismoydeporte/opencms/areas/turismo/registro-de-turismo/ Ryan, C. (1991). Recreational Tourism. London: Routledge. 
Sharpley, R. (2014). Host perceptions of tourism: A review of the research. Tourism Management, 42, 37-49. https://doi.org/10.1016/j.tourman.2013.10.007

Sosa, A., \& Jiménez, A. (2010). Crónica de un conflicto anunciado (o de-nunciado): el caso de Playa Delfines en Cancún. In E. Cañada (Coord.), Turismo en Centroamérica: un nuevo escenario de conflictividad. Managua: Editorial Enlace.

Troncoso, A. (2018). Venice: the problema of overtourism and the impact of cruises. $\begin{array}{llll}\text { Investigaciones } & \text { Regionales, } & \text { 42, } & \text { Retrieved }\end{array}$ from https://investigacionesregionales.org/article/venice-the-problem-of-overtourism-and-theimpact-of-cruises/

Turner, L., \& Ash, J. (1975). The golden hordes: International tourism and the pleasure periphery. Constable \& Ro.

Vanderwerf, J. (2008). Creative Destruction and Rural Tourism Planning: The Case of Creemore. Ontario: UWSpace. Retrieved from: http://hdl.handle.net/10012/3809

Vianello, M. (2016). The No Grandi Navi campaign: protests against cruise tourism in Venice. In C. Colomb \& C. Nowy (Eds.), Protest and resistance in the tourist city (pp. 185-204). London: Routledge. https://doi.org/10.4324/9781315719306

Vives-Miró, S., \& Rullan, O. (2017). ¿Desposesión de vivienda por turistización?: Revalorización y desplazamientos en el Centro Histórico de Palma (Mallorca). Revista de Geografía Norte Grande, (67), 53-71. http://dx.doi.org/10.4067/S0718-34022017000200004

Wall, G., \& Mathieson, A. (2006). Tourism: Changes, Impacts, and Opportunities. Essex: Pearson Education Unlimited

Zerva, K., Palou, S., Blasco, D., \& Donaire, J.A. (2019). Tourism-philia versus tourism-phobia: residents and destination management organization's publicly expressed tourism perceptions in Barcelona. Tourism Geographies, 21(2), 306-329.

https://doi.org/10.1080/14616688.2018.1522510 